\title{
Analgesic Effectiveness and Improvement in Quality of Life after Using Topical Sevoflurane for an Extremely Painful Anal Fissure
}

\section{Eficácia analgésica e melhoria da qualidade de vida com o uso tópico de sevoflurano em fissura anal extremamente dolorosa}

\author{
Jesús Cifuentes-Tébar ${ }^{10}$ Juan Luis Rueda-Martínez ${ }^{2}$ \\ Manuel Gerónimo-Pardo ${ }^{4}$ \\ ${ }^{1}$ Coloproctology Section, Department of General Surgery, Complejo \\ Hospitalario Universitario, Albacete, Spain \\ 2 Department of General Surgery, Complejo Hospitalario \\ Universitario, Albacete, Spain \\ ${ }^{3}$ Department of Applied Economy, Universidad de Castilla-La Mancha, \\ Albacete, Spain \\ ${ }^{4}$ Department of Anesthesiology, Complejo Hospitalario Universitario, \\ Albacete, Spain
}

J Coloproctol 2021;41(2):206-209.

\author{
Carmen Selva-Sevilla30
}

\begin{abstract}
Address for correspondence Manuel Gerónimo-Pardo, Ph.D. Departamento de Anestesiología, Complejo Hospitalario Universitario de Albacete, Hermanos Falcó 37, 02006 Albacete, España (e-mail: mgeronimop@sescam.jccm.es; sergepu@hotmail.com).
\end{abstract}

\begin{abstract}
Painful anal fissures could be distressing conditions that severely impair the patients' quality of life. The analgesic effectiveness of topical drugs, such as calcium-antagonists and nitrates is quite variable. The inhalational anesthetic sevoflurane is being repurposed as a topical analgesic for painful chronic wounds. We report a pioneer experience treating a painful chronic anal fissure with topical sevoflurane. A young adult male was suffering from an extremely painful chronic anal fissure, which severely affected his quality of life. The topical treatment with nitroglycerine and diltiazem gels failed. The

\section{Keywords}

- sevoflurane

- administration

- topical

- fissure in ano

- pain

- quality of life patient agreed to the treatement with topical sevoflurane as an off-label medication, and it produced an immediate, intense, and long-lasting analgesic effect. An intense but rapidly transient burning sensation, as well as persistent but well-tolerated flatulence were the only adverse effects. The quality of life was greatly improved, and the cost of the treatment was affordable. Therefore, the off-label use of topical sevoflurane appears to be an effective alternative for the symptomatic treatment of painful anal fissures.
\end{abstract}

received

August 7, 2020

accepted

August 23, 2020

published online

May 24, 2021
DOI https://doi.org/

10.1055/s-0041-1724067.

ISSN 2237-9363. (c) 2021. Sociedade Brasileira de Coloproctologia. All rights reserved.

This is an open access article published by Thieme under the terms of the Creative Commons Attribution-NonDerivative-NonCommercial-License, permitting copying and reproduction so long as the original work is given appropriate credit. Contents may not be used for commercial purposes, or adapted, remixed, transformed or built upon. (https://creativecommons.org/ licenses/by-nc-nd/4.0/)

Thieme Revinter Publicações Ltda., Rua do Matoso 170, Rio de Janeiro, RJ, CEP 20270-135, Brazil 


\section{Resumo}

\section{Palavras-chave}

- sevoflurano

- administração tópica

- fissura anal

- dor

- qualidade de vida
As fissuras anais dolorosas podem ser condições angustiantes que prejudicam gravemente a qualidade de vida dos pacientes. A eficácia analgésica de medicamentos tópicos, como antagonistas de cálcio e nitratos, é bastante variável. O anestésico inalatório sevoflurano está sendo reaproveitado como analgésico tópico para feridas crônicas dolorosas. Relatamos uma experiência pioneira de tratamento com sevoflurano tópico em fissura anal crônica dolorosa. Um jovem adulto do sexo masculino sofria de uma fissura anal crônica extremamente dolorosa, que afetava gravemente sua qualidade de vida. O tratamento tópico com nitroglicerina e géis de diltiazem foi ineficaz. O paciente concordou com o tratamento com sevoflurano tópico como medicamento off-label, ou seja, com uso diferente do aprovado em bula. O sevoflurano tópico produziu um efeito analgésico imediato, intenso e duradouro. Uma sensação de ardência intensa, mas transitória, e flatulência persistente, embora bem tolerada, foram os únicos efeitos adversos. A qualidade de vida melhorou significativamente, e o custo do tratamento revelou-se acessível. Portanto, o uso off-label de sevoflurano tópico pode ser uma alternativa analgésica eficaz em casos de fissuras anais dolorosas.

\section{Introduction}

Anal fissures have the potential to be distressing conditions; patients can suffer from extremely severe defecatory pain, for instance. Overall, this disease may also greatly impair the quality of life of patients. $^{1-4}$

The ultimate etiology has been suggested to be mediated by an ischemic event caused by a maintained hypertonia of the internal anal sphincter. The definitive surgical treatment consists of an internal anal sphincterotomy. Concerning the nonsurgical treatment, topical gels containing diltiazem or nitroglycerin are intended to relax the sphincter, and, consequently, reduce the pain, but their effectiveness is quite variable, and their adverse effects occasionally make them useless. ${ }^{2-4}$

The general anesthetic sevoflurane is becoming a novel alternative for chronic ulcers. When applied topically on painful wounds, this drug has shown to exert a rapid, intense, and long-lasting analgesic effect, regardless of the etiology of the wound or the refractoriness of the pain to conventional analgesics. ${ }^{5-7}$ Currently, sevoflurane is marketed exclusively for hospital use, but home treatment is possible under an offlabel indication. ${ }^{6,8}$ As a result, the patients' quality of life could be greatly improved. ${ }^{8,9}$ Taking all the aforementioned information into consideration, topical sevoflurane could be an effective new alternative for the ambulatory analgesic treatment of painful anal fissures, as the case herein reported exemplifies.

\section{Case Report}

A 40-year-old male was suffering from defecatory pain and bleeding for the previous 2 years, mainly when experiencing stressful situations such as a period of unemployment. A chronic anal fissure was diagnosed at a visit to the proctology clinic, and topical treatment was prescribed in addition to general hygiene measures. However, the use of nitroglycerine gel was ceased due to intolerable adverse effects, and diltiazem cream proved to be ineffective in controlling the pain.
In the previous two months, the clinical condition had worsened remarkably. The patient referred noticeably high pain scores for daily activities (10 points out of 10 at defecation, 8 points when sitting, and 5 points when standing, according to the numerical rating scale), and the pain also interfered with night rest. He had lost $11 \mathrm{~kg}$ due to aversion to eating for fear of the inevitable subsequent defecation. Overall, his quality of life was greatly affected.

An internal lateral sphincterotomy was proposed to the patient, but the surgical waiting list was very long. Given this scenario, he agreed in writing to be treated with off-label topical sevoflurane.

The very first treatment consisted of the self-application of $3 \mathrm{~mL}$ of sevoflurane into the rectum. It caused an immediate and intense burning sensation, followed in a few seconds by an intense analgesic effect.

The analgesic effect lasted for approximately two days, and it was long-lasting enough to enable the application of sevoflurane every two or three days from then on, as needed. The pain associated to daily activities was controlled ever since the first application, even the defecatory pain; thus, he could regain night rest and his aversion to eating disappeared.

The burning sensation became a minor discomfort from the third application on. Then, the most relevant adverse effect was flatulence through the rectum for one or two hours after each application.

A new consultation a month later revealed that the fissure had healed, and the application of sevoflurane was discontinued. Although not properly studied, both the cost-effectiveness and cost-utility would possibly be favorable in this case. Regarding costs, the cost of the of direct acquisition a $250-\mathrm{mL}$ bottle of sevoflurane from the Pharmacy Department was of $€$ 72.76 in 2019; thus, each 3-mL application costed 87.3 cents. Regarding effectiveness, the pain was fully controlled. The quality of life was greatly improved, as assessed by two generic health questionnaires: the EuroQol Five-Dimension ThreeLevel (EQ-5D-3L), which refers to the health status on the day of the application of the survey (-Table 1); and the 36-item 
Table 1 Health outcomes obtained with the EuroQol FiveDimension Three-Level (EQ-5D-3L) quality of life generic questionnaire

\begin{tabular}{|l|l|l|l|}
\hline & $\begin{array}{l}\text { Range of } \\
\text { possible } \\
\text { values }\end{array}$ & Baseline & Sevoflurane \\
\hline Mobility & $1-3^{\mathrm{a}}$ & 2 & 1 \\
\hline Self-care & $1-3^{\mathrm{a}}$ & 2 & 1 \\
\hline $\begin{array}{l}\text { Activities of } \\
\text { daily life }\end{array}$ & $1-3^{\mathrm{a}}$ & 2 & 1 \\
\hline Pain & $1-3^{\mathrm{a}}$ & 2 & 1 \\
\hline Anxiety/Depression & $1-3^{\mathrm{a}}$ & 1 & 1 \\
\hline $\begin{array}{l}\text { EuroQol Visual } \\
\text { Analogue Scale } \\
\text { (EQ-VAS) }\end{array}$ & $0-100^{\mathrm{b}}$ & 15 & 95 \\
\hline $\begin{array}{l}\text { Utility (of the } \\
\text { EQ-5D-3L) }\end{array}$ & $0-1^{\mathrm{b}}$ & 0.5442 & 1.0000 \\
\hline
\end{tabular}

Note: Higher scores correspond to worse ${ }^{\mathrm{a}}$ or better ${ }^{\mathrm{b}}$ health status.

Short-Form Health Survey (SF-36), version 2, which refers to the health status for the four weeks preceding the application (-Table 2).

The clinical picture recurred two months later in the setting of a stressful personal and work situation. Upon examination, an extremely painful new anal fissure was diagnosed. Treatment with topical sevoflurane was restarted, but this time it was kept refrigerated and it was not applied intrarectally, but directly on the fissure. After these two modifications, the patient experienced the same intense and long-lasting analgesic effect, but the flatulence nearly disappeared.

The patient is currently waiting to undergo a sphincterotomy, but the addition of topical sevoflurane to the general hygiene measures keeps the pain under control, and he enjoys a good quality of life.

Written informed consent for the publication of the clinical details of the patient was obtained. A copy of the consent form is available for review by the Editor of this journal.

Table 2 Health outcomes of the 6 dimensions (6D) of the Short-Form 6D (SF-6D), which was obtained from the Short Form-36 Health Survey, version 2

\begin{tabular}{|l|l|l|l|}
\hline & $\begin{array}{l}\text { Range of } \\
\text { possible } \\
\text { values }\end{array}$ & Baseline & Sevoflurane \\
\hline Physical functioning & $1-6^{\mathrm{a}}$ & 3 & 1 \\
\hline Role emotional & $1-4^{\mathrm{a}}$ & 1 & 2 \\
\hline Social functioning & $1-5^{\mathrm{a}}$ & 4 & 1 \\
\hline Pain & $1-6^{\mathrm{a}}$ & 5 & 2 \\
\hline Mental health & $1-5^{\mathrm{a}}$ & 5 & 2 \\
\hline Vitality & $1-5^{\mathrm{a}}$ & 3 & 1 \\
\hline $\begin{array}{l}\text { Utility } \\
\text { (of the SF-6D) }\end{array}$ & $0-1^{\mathrm{b}}$ & 0.2160 & 0.9020 \\
\hline
\end{tabular}

Note: Higher scores correspond to worse ${ }^{\mathrm{a}}$ or better $^{\mathrm{b}}$ health status.

\section{Discussion}

The rapid, intense, and long-lasting analgesic effect of topical sevoflurane enabled this patient to immediately regain his quality of life; morevoer, the medication is affordable.

The analgesic effect of topical sevoflurane on wounds is usually felt in a few minutes, but, remarkably, it was nearly immediate in this case. It has been suggested that sevoflurane must diffuse to the free nerve endings to exert its analgesic effect. ${ }^{5}$ Chronic wounds can have barriers to diffusion, such as detritus or slough, which could explain the reported delay of a few minutes for the analgesic effect to be felt. ${ }^{7}$ On the contrary, the anal mucosa usually lacks such barriers, enabling an immediate diffusion of a lipophilic drug such as sevoflurane to the exposed nociceptors.

The analgesic effect of topical sevoflurane has been reported to last for several hours in cases of chronic painful wounds. Patients suffering from such wounds are usually elderly and also suffer from cardiovascular diseases. ${ }^{7,9}$ In such a scenario, clearance of sevoflurane from the wound bed to the venous systemic circulation should happen at a low rate, making it possible to prolong the analgesic effect. But our clinical scenario involving a healthy young male suffering from a fissure in a well-perfused zone was completely different. Thus, the analgesic effect lasted much longer than that expected from a direct pharmacological action on the nociceptors of the anal mucosa. Interestingly, a likely explanation for the long effect could be based on a direct effect of sevoflurane on the internal anal sphincter. This is a smooth muscle, and one study ${ }^{10}$ supports the myorelaxant effect of sevoflurane on the smooth muscles of the cardiovascular system. More interestingly, sevoflurane was found to inhibit the contraction of the human uterine smooth muscle. ${ }^{11}$ Thus, maybe sevoflurane could alleviate pain as a consequence of a direct relaxant action on the internal anal sphincter. Additionally, the aforementioned vasodilatory effect could also contribute to improve local perfusion, which would favor healing; this possibility has been theorized for hard-to-heal wounds. ${ }^{9}$ Both these hypotheses result attractive and deserve further research.

Concerning safety, the initial intense burning sensation soon became a well-tolerated mild discomfort; it could be similar to the frequently-reported transient itching appearing in chronic wounds. ${ }^{7}$ As for flatulence, it was likely caused by sevoflurane itself exiting from the rectum as a gas. It should be taken into account that, at $37^{\circ} \mathrm{C}$, each milliliter of liquid sevoflurane volatilizes into $195 \mathrm{~mL}$ of gas, ${ }^{12}$ and flatulence was clearly reduced after applying refrigerated sevoflurane.

\section{Conclusion}

To conclude, topical sevoflurane seems to be an effective alternative for the symptomatic treatment of painful anal fissures. As for the wounds, the analgesic effect produced was rapid, intense, and long-lasting. The risk-benefit profile seemed to be favorable as well, while the costs seemed affordable. Further research on this new indication for an old drug is warranted. 
Financial Support

No funds were received either to treat the patient or to publish this case report.

\section{Conflict Of Interest}

Manuel Gerónimo-Pardo owns stock options from Vapogenix Inc., Houston, US, and also received honoraria for consultation. The rest of the authors have no conflict of interests to declare.

\section{Acknowledgements}

The authors are very grateful to Mr. Johnathan S.F. Kelleher and Dr. Jose Vidoedo for their kind help with the English and Portuguese translations respectively.

\section{References}

1 Griffin N, Acheson AG, Tung P, Sheard C, Glazebrook C, Scholefield $\mathrm{JH}$. Quality of life in patients with chronic anal fissure. Colorectal Dis 2004;6(01):39-44. Doi: 10.1111/j.1463-1318.2004.00576.x

2 Ortiz H, Marzo J, Armendáriz P, DeMiguel M, Blasi ML. [Fissure-inano. Alterations in continence and quality of life during disease and at six months after lateral subcutaneous internal sphincterotomy]. [in Spanish]. Cir Esp 2005;77(02):91-95

3 Tsunoda A, Kashiwagura Y, Hirose K, Sasaki T, Kano N. Quality of life in patients with chronic anal fissure after topical treatment with diltiazem. World J Gastrointest Surg 2012;4(11):251-255. Doi: $10.4240 /$ wjgs.v4.i11.251

4 Arısoy Ö, Sengül N, Çakir A. Stress and psychopathology and its impact on quality of life in chronic anal fissure (CAF) patients. Int J Colorectal Dis 2017;32(06):921-924. Doi: 10.1007/s00384-016-2732-1
5 Gerónimo-Pardo M, Martínez-Monsalve A, Martínez-Serrano M. Analgesic effect of topical sevoflurane on venous leg ulcer with intractable pain. Phlebologie-Stuttgart 2011;40:95-97. Doi: $10.1055 / \mathrm{s}-0037-1621757$

6 Fernández-Ginés FD, Cortiñas-Sáenz M, Mateo-Carrasco H, et al. Efficacy and safety of topical sevoflurane in the treatment of chronic skin ulcers. Am J Health Syst Pharm 2017;74(09):e176-e182. Doi: 10.2146/ajhp151008

7 Martínez-Monsalve A, Selva-Sevilla C, Gerónimo-Pardo M. Analgesic effectiveness of topical sevoflurane to perform sharp debridement of painful wounds. J Vasc Surg 2019;69(05):1532-1537. Doi: 10.1016/j.jvs.2018.08.175

8 Fernández-Ginés FD, Cortiñas-Sáenz M, Selva-Sevilla C, Gerónimo-Pardo M. Sevoflurane topical analgesia for intractable pain with suicidal ideation. BMJ Support Palliat Care 2020. Online ahead of print. https://doi.org/10.1136/bmjspcare-2019-002023

9 Pinar-Sánchez J, Gerónimo-Pardo M. Topical sevoflurane as rescue therapy in a frail patient suffering from leg ulcers causing refractory pain and superinfected by methicillin-resistant Staphylococcus aureus and sensitive Pseudomonas aeruginosa. Case report. [in Spanish]Med Paliat 2020;27:263-267. Doi: 10.20986/medpal.2020.1130/2019

10 Thorlacius K, Bodelsson M. Sevoflurane promotes endotheliumdependent smooth muscle relaxation in isolated human omental arteries and veins. Anesth Analg 2004;99(02):423-428. Doi: 10.1213/01.ANE.0000121771.78755.F4

11 Yoo KY, Lee JC, Yoon MH, et al. The effects of volatile anesthetics on spontaneous contractility of isolated human pregnant uterine muscle: a comparison among sevoflurane, desflurane, isoflurane, and halothane. Anesth Analg 2006;103(02):443-447. Doi: 10.1213/01. ane.0000236785.17606.58

12 Biro P. Calculation of volatile anaesthetics consumption from agent concentration and fresh gas flow. Acta Anaesthesiol Scand 2014;58(08):968-972. Doi: 10.1111/aas.12374 